\title{
Correlation between chemical and mineralogical characteristics and permeability of phyllite clays using multivariate statistical analysis
}

\author{
E. Garzón ${ }^{\mathrm{a}}$, E. Romero ${ }^{\mathrm{b}} \&$ P.J. Sánchez-Soto ${ }^{\mathrm{c}}$
}

\section{Affiliation:}

a Departamento de Ingeniería, Universidad de Almería, La Cañada de San Urbano, 04120 Almería, Spain

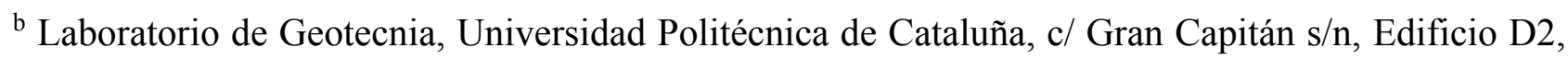
Barcelona, Spain

${ }^{\mathrm{c}}$ Instituto de Ciencia de Materiales, Centro Mixto Consejo Superior de Investigaciones Científicas (CSIC), Universidad de Sevilla, c/Américo Vespucio 49, Edificio cicCartuja, 41092 Sevilla, Spain

* Contact details (corresponding author):

Eduardo Garzón

e-mail: egarzon@ual.es 


\begin{abstract}
Phyllite clays are applied as a layer on a surface to be waterproofed and subsequently compacted. For this purpose, phyllite clays deposits can be grouped by their chemical and mineralogical characteristics, and these characteristics can be connected with their properties, mainly permeability, in order to select those deposits with the lowest permeability values. Several deposits of phyllite clays in the provinces of Almería and Granada (SE Spain) have been studied. The results of applying a multivariate statistical analysis (MVA) to the chemical data analysed from 52 samples determined by XRF, mineralogical analysis by XRD and permeability are reported. Permeability, a characteristic physical property of phyllite clays, was calculated using the results for experimental nitrogen gas adsorption and nitrogen adsorption-desorption permeability dependence. According to the results, permeability values differentiated two groups, i.e. group 1 and group 2, with two subgroups in the latter. The influence of chemical as well as mineralogical characteristics on the permeability values of this set of phyllite clays was demonstrated using a multiple linear regression model. Two regression equations were deduced to describe the relationship between adsorption and desorption permeability values, which support this correlation. This was an indication of the statistical significance of each chemical and mineralogical variable, as it was added to the model. The statistical tests of the residuals suggested that there was no serious autocorrelation in the residuals.
\end{abstract}

Keywords: Multivariate analysis, permeability, phyllite clays 


\section{Introduction}

Phyllite clays or phyllites are foliated rocks, metamorphosed to a low extent, because they are formed by low-temperature regional metamorphism, of slate clay materials. Their essential components are an abundance of very fine-grained phyllosilicates, which gives them an unctuous feel, and quartz; occasionally, they may contain calcite (calcareous phyllites). The existence of preferential cleavage gives them the property of being easily breakable into thin sheets (Garzón et al., 2009a, 2009b; Garzón et al., 2010; Oliva-Urcia et al., 2010; Oliveira et al., 2015; Ramamurthy et al., 1993; Valera et al., 2002). Their colours range from beige to violet and from reddish to gray and black. Although found in several parts of the world, phyllite clays are abundant in the Betic Cordilleras (Andalusia, S Spain), e.g. in the provinces of Almería and Granada, mainly in Alpujarride and Malaguide Complex (Alcántara-Ayala, 1999; Azañón et al., 1995; Crespo-Blanc, 1995; Gómez-Pugnaire et al., 1978; Lonergan and Platt, 1995; Sanz de Galdeano, 1990; Sanz de Galdeano et al., 2001; Sanz de Galdeano and López-Garrido, 2014). The nature of the contact between Alpujarride and Malaguide complexes has been discussed by Lonergan and Platt (1995). The tectonic map of the central Betics, geological setting and structure of the Alpujarride Complex, cross-sections and other notable features have been reported by Azañón et al. (1995). Sanz de Galdeano et al. (2001) concluded that the presence of the Intermediate Units indicates that the change from the Alpujarride to Malaguide complexes was not abrupt, but rather occurred with a wide transitional domain between them.

In Sierra Nevada (SE Spain), phyllites form a band of Permo-Triassic materials (slate, marble, and clay phyllites). In Sierra Alhamilla (Almería) there is a phyllite area in blue, violet, and reddish colours in which limestone and dolomite can be found, separated by a transition area of calco-schists. All these materials belong to the Alpujarride Complex (Alcántara-Ayala, 1999; Crespo-Blanc, 1995; Gómez-Pugnaire et al., 1978; Lonergan and Platt, 1995; Sanz de Galdeano, 1990; Sanz de Galdeano and López-Garrido, 2014). The northern and western borders of the Sierra Cabrera (Almería) have several outcrops considered to belong to the Malaguide complex with dark Palaeozoic lutites and Jurassic and Tertiary sediments: its Triassic sequences are formed by phyllites (Sanz de Galdeano et al., 2001). Small outcrops are also found in the Sierra de Alhamilla (Almería), in particular on the northern border, some in the south, and a few in the east where this sierra joins the Sierra Cabrera (Sanz de Galdeano et al., 2001). The geological setting and morphology of the Sierra de Lújar, crosssections and main features of the other units, have been studied and reported by Sanz de Galdeano and López-Garrido (2014). Phyllites have been described by these authors on studying the stratigraphic series of the Lújar unit. In other parts of eastern Andalusia, such as the Baza mountain range (Granada), the presence of phyllites has also been reported in an early work by Gómez-Pugnaire 
et al., 1978. Furthermore, the Alpujarra phyllites have undergone several en-masse movements as a consequence of sliding and/or flow processes. These movements are conditioned, among other factors, by the dipping angle of the slopes, and the low shear strength and the humidity of the material (Alcántara-Ayala, 1999).

In recent years, a few publications have reported on different applications of phyllite clays in materials technology, for instance in concrete (Ramamurthy et al., 1993), as a filler in plastic (Valera et al., 2002) and mortar (Oliveira et al., 2015) products. In SE Spain, due to their low water permeability, their compacting properties, their relative low cost and their abundance, phyllite clays in a variable state of trituration have been traditionally used for very specific purposes, such as: a covering and waterproofing for roofs; layers and subsequently compacted, of buildings; in the central area of ponds; core material in zoned dams and also for urban waste landfill applications (Alcántara-Ayala, 1999; Garzón et al., 2010; Garzón et al., 2015a, 2015b; Suárez et al., 2005). Garzón et al. (2010) studied and reported the physical and geotechnical properties of phyllite clays. Garzón et al. (2015a, 2015b) reported phyllite clay-cement composites having improved engineering properties and material applications, such as roofs, building construction, and flexible pavements. Waterproof compositions have also been developed using phyllite clays as raw materials (Spanish Patent by Garzón et al., 2015a, 2015b). Recently, Garzón et al. (2016) studied the effect of lime on stabilization of phyllite clays. Potential applications of these mixtures include earth construction, building materials, and impermeabilization. However, due to the variability in the chemical and mineralogical composition of phyllite clays on which their properties depend, as well as on their potential applications, it becomes useful to characterize these clay materials from each zone. Only through a good state-ofthe-art knowledge of the chemical and mineralogical composition and the physical properties of the phyllite clays in each zone will it be possible to understand their traditional uses and to try to improve them. This knowledge is also important to assess the properties of phyllite clays in other regions and to evaluate their potential uses in applications other than traditional ones. Statistical methods prove helpful for this purpose. For instance, Galán et al. (1995) proposed the multivariate statistical analysis as a tool for genetic approaches in clay mineralogy and further to study the correlation of some properties of kaolin with its mineralogical and chemical composition (Galán et al., 1998).

The aim of the present work was to assess the application of multivariate statistical analysis to study a set of phyllite clay deposits (52 samples) in a study zone (Almería and Granada, SE Spain), where the main geological features have been previously described, as pointed out above, and to examine the possible existence of correlations between both the chemical and mineralogical characteristics on a physical property of these samples. The most relevant physical property of the phyllite clays is 
permeability and, hence, this was examined. These phyllite clay deposits can thus be selected with the lowest permeability values for their applications.

\section{Experimental}

\subsection{Samples}

In this study, a total of 52 phyllite clay samples from several deposits in Almería and Granada provinces (Andalusia Region, Spain) were studied. The identification, description, and their GPS location of all these samples have previously been reported (Garzón et al., 2009b; Garzón et al., 2012). Fig. 1 shows the spatial location of each and includes the different deposits, identification, and localization data with $\mathrm{X}$ and $\mathrm{Y}$ coordinates and altitudes in the study areas. The selection of the sampling areas was based on the geological and mining maps available and precludes the possibility that all these samples were of similar origin. A previous study was performed using the geological maps MAGNA scale 1:50,000 and the Mineralogical-Geological Map of the Region of Andalusia scale 1:400,000. Thus, the zones with phyllite clays at the surface were selected and later, in situ, the samples were mined. In general, the thickness of phyllite clay deposits was variable, but after removing the first surface layer $(1-30 \mathrm{~cm})$, the thicknesses were $1-2 \mathrm{~m}$.

\subsection{Chemical analysis by X-ray fluorescence}

X-ray fluorescence analysis (XRF)were performed on pellets obtained from pressed powered samples using an Axios PANalytical B.V. equipment located at the 'Centro de Investigación, Tecnología e Innovación de la Universidad de Sevilla (CITIUS)', with a sample handling maximum of $51.5 \mathrm{~mm}$ diameter and $40 \mathrm{~mm}$ height, $0.5 \mathrm{rev} / \mathrm{s}$ spinner. The X-ray tube was a super-sharp end-window tub with Rh standard anode, ceramic insulation and ultra-high transmission. The goniometer type was $\theta / 2 \theta$ decoupled with Direct Optical Position System, angular accuracy $0.0025^{\circ} \theta$ and $2 \theta$, angular reproducibility $0.0001^{\circ} \theta$ and $2 \theta$ and temperature stabilization $\pm 0.05^{\circ} \mathrm{C}$ at $31^{\circ} \mathrm{C}$ cabinet temperature. The electronic counting was carried out with a dual multi-channel analyser with a digital signal processor having automatic dead-time correction. The crystals were: LiF420, LiF220, LiF200, Ge111 (flat/curved), T1AP coated, PX1, PX4, PX5, PX6, PX7, and PX9. The quality of the analytical results concerning their precise and accurate characteristics was checked by measurements using standard certified materials at the CITIUS, such as GEOPT19, GEPT20, and NCS DC7 1301 of the International Association of Geoanalysts, recommended after proficiency tests for analytical geochemistry laboratories (Sena et al., 1995). 


\subsection{Mineralogical analysis}

The mineralogical analysis of the 52 samples was determined by Xray powder diffraction (XRD). The samples were gently ground in an agate mortar. Samples were scanned in random preparations using a X-ray diffractometer Bruker D-501 at the ICMS with Ni-filtered CuKa radiation, graphite monochromator, at $36 \mathrm{kV}$ and $26 \mathrm{~mA}$ and a scanning speed of $1^{\circ}$ in $2 \theta$ min- 1 . The mineralogical composition after crystalline phase analysis was determined using the methods proposed by Schultz (1964) and Biscaye (1965) applied in previous research by several authors such as López et al. (1971); Parras et al. (1996); Jordán et al. (1999); Dolinar et al. (2007), and Carretero et al. (2014). In the present study, however, the modifications provided by Galán and Espinosa de los Monteros (1974) were considered for all the samples in order to perform these calculations (García-Ramos et al., 1985; Mesa López-Colmenar, 1986; Garzón et al., 2010). From the X-ray diagnostic peaks of each mineral phase, the peak areas were measured. The source of errors that influence the shape of XRD diagrams, such as background, orientation of phyllosilicates, and grinding of the samples, were avoided.

\subsection{Surface area and nitrogen adsorption-permeability dependence}

The surface area and pore structure of the natural samples were determined using nitrogen adsorption at liquid nitrogen temperature. Micromeritics-ASAP 2010 equipment was used. Surface areas were estimated from the Brunauer, Emmett, and Teller (BET) model along the adsorption branch (Brunauer et al., 1938; Sing et al., 1985). The pore size distribution and cumulative pore area were estimated following the Barrett, Joyner, and Hallenda (BJH) method using the adsorption desorption information (Barrett et al., 1951; Sing et al., 1985).

Although it was possible to determine permeability by direct measurements, it was informative to investigate the dependence of this parameter with adsorption-desorption of nitrogen gas at liquid nitrogen temperature for the 52 samples but for small pore sizes. Several mathematical methods have been developed to correlate nitrogen-adsorption results with saturated-water permeability, such as capillary, hydraulic radius, and probabilistic models (García-Bengochea et al., 1979; Juang and Holtz, 1986a; Juang and Holtz, 1986b). Predictive equations enabled us to demonstrate the dependence of permeability on pore-size distribution and reflected its changes induced by different stress paths. The different models were based on the Hagen-Poiseuille equation for laminar flow through a cylindrical capillary of diameter x (García-Bengochea et al., 1979; Lapierre et al., 1990; Vicol, 1990). The main difference arises in the way two cross-sections ( $i$ and $j$ separated by a distance $L$ ), with identical poresize density function and defining a flow region, are considered to be connected. 
The probability $P\left(x_{i}, x_{j}\right)$ of pores of sizes between $x_{i}$ and $x_{i}+\mathrm{d} x_{i}$ on cross-section $i$ to be connected to pores of sizes between $x_{j}$ and $x_{j}+\mathrm{d} x_{j}$ on cross-section $j$, presents the following extreme cases (Juang and Holtz, 1986b):

- For $L>>x$, the connection can be assumed to be completely random, where each section is independent of the other, and hence the probability is $P\left(x_{i}, x_{j}\right)=\mathrm{f}\left(x_{i}\right) \mathrm{f}\left(x_{j}\right) \mathrm{d} x_{i} \mathrm{~d} x_{j}$. The term $\mathrm{f}(x) \mathrm{d} x$ represents the fraction of pore volume, which is assumed to be equal to the area ratio, contributed by pores between $x$ and $x+\mathrm{d} x$, where $\mathrm{f}(x)$ is the pore size density function.

- For $\mathrm{L} \rightarrow 0$ the pores considered are correlated, and hence the probability is $P\left(x_{i}, x_{j}\right)=\mathrm{f}\left(x_{i}\right) \mathrm{d} x_{i}$ or $\mathrm{f}\left(x_{j}\right) \mathrm{d} x_{j}$.

For the sake of simplicity, an expression equivalent to the classical capillary concept of correlated pores has been selected for the permeability model, though it is clear that the porous media is extremely disordered. For a distribution of capillaries, García-Bengochea et al. (1979) formulated the following equation for calculating the permeability $k_{w}$ :

$$
\mathrm{k}_{\mathrm{w}}=\frac{\rho_{\mathrm{w}} \mathrm{gx}^{2}}{32 \mu} ; \quad \mathrm{k}_{\mathrm{w}}\left(\mathrm{x}_{\mathrm{m}}\right)=\frac{\rho_{\mathrm{w}} \mathrm{gn}}{32 \mu} \sum_{\mathrm{i}}^{\mathrm{m}} \mathrm{x}_{\mathrm{i}}^{2} \overline{\mathrm{f}}\left(\mathrm{x}_{\mathrm{i}}\right)
$$

where $\rho_{w}$ is the water density at a certain temperature, $g$ the gravitational acceleration, $\mu$ the coefficient of absolute viscosity of water at a specified temperature, $n$ the porosity of the soil and $\overline{\mathrm{f}}\left(\mathrm{x}_{\mathrm{i}}\right)$ the frequency histogram. The second moment about the origin of the histogram represents the number of pores of size $x_{i}$ multiplied by the pore area. The area frequency of the capillary diameter $x_{i}$ is admitted to be equivalent to the volumetric frequency, which is the quantity measured in the nitrogen adsorption method. The factor $n$ converts the $S r_{n w}$ values to equivalent ones related to gross crosssectional areas.

Relative permeability values $k_{w}\left(x_{i}\right) / k_{w}\left(x_{m}\right)$ for different pore sizes ( $x_{m}$ represents the maximum pore diameter) can also be calculated.

Finally, in order to introduce the pore-size density function as suggested in the second case for correlated pores, Eq. (1) transforms to: 


$$
\mathrm{k}_{\mathrm{w}}\left(\mathrm{x}_{\mathrm{m}}\right)=\frac{\rho_{\mathrm{w}} \mathrm{gn}}{32 \mu} \int_{0}^{\mathrm{x}_{\mathrm{m}}} \mathrm{x}^{2} \mathrm{f}(\mathrm{x}) \mathrm{dx}
$$

Thus, indirect values of permeability in the range of small pore sizes $0.17-25 \mathrm{~nm}$ were estimated using this model for the 52 phyllite clay samples.

\subsection{Multivariate statistical analysis}

To isolate and estimate the statistic validity of those groups that showed a similar profile, we analysed the permeability (determined in the adsorption and desorption phases) with two exploratory multivariate-analysis techniques: cluster analysis and discriminant canonical analysis, which include the Mahalanobis distance calculation (Mommsen, 2001). Finally, a multiple-regression analysis of permeability using adsorption (ADS) and desorption (DESOP) experimental results was performed to assess the influence of both chemical and mineralogical characteristics of the 52 phyllite samples. For this purpose, the program Statgraphic-plus was used. Autocorrelation in the residuals and the results of fitting a multiple linear regression model were examined. The confidence levels were also determined for both ADS and DESOP.

\section{Results}

The results of the chemical analyses by XRF in the 52 phyllite samples have been previously reported (Garzón et al., 2009a, 2009b; Garzón et al., 2010; Garzón et al., 2012). The chemical composition demonstrated a predominance of silica (maximum66.61wt.\% in sample 45) and alumina (maximum $27.32 \mathrm{wt} . \%$ in sample 5), with variable content of iron oxides (maximum 8.99 wt.\% in sample 11), calcium oxide (maximum14.24wt.\% in sample 6) and other minor components (Table 1). The numerical analyses indicated that there were 41 variables: 10 macroelements and 31 trace elements. The macroelements were the following: $\mathrm{SiO}_{2}, \mathrm{Al}_{2} \mathrm{O}_{3}, \mathrm{Fe}_{2} \mathrm{O}_{3}, \mathrm{MnO}, \mathrm{MgO}, \mathrm{CaO}, \mathrm{Na}_{2} \mathrm{O}, \mathrm{K}_{2} \mathrm{O}, \mathrm{TiO}_{2}$, and $\mathrm{P}_{2} \mathrm{O}_{5}$. The remaining variables represented only $0.06 \%$. Consequently, the trace elements were not significant.

The results of mineralogical analysis by XRD have been previously reported (Garzón et al., 2012). From these results, as summarized in Table 2, it was found that the mineral content ranges (in wt.\%): $30-85 \%$ of quartz, 5-25\% mica (illite), 2-23\% chlorite, 3-18\% feldspar (microcline), 0-15\% iron oxide (hematite and/or goethite), and dolomite (0-32\%). However, smaller proportions of the 
following crystalline phases have also been identified: calcite (0-8\%) and an interstratified or mixedlayer clay mineral (IS), although it was difficult to estimate their relative proportion. In general, the relative proportion of IS is $<2 \mathrm{wt} . \%$ or not detected.

Concerning the indirect permeability results determined and reported in the present work (Table 2), the cluster analysis was carried out following the results of permeability found in the adsorption (namely ADS) and desorption (namely DESOP) phases, using the nearest-neighbour method and an Euclidean distance matrix. The results gave a dendrogram with two clearly differentiated groups (Fig. 2a):

Group 1: sample 23, which include the samplewith the highest permeability value.

Group 2: the rest of the samples.

Within this group 2 there were further groupings:

Subgroup 1: samples 47 and 10, which consisted of a set of phyllite clay samples with the highest impermeability in the adsorption phase.

Subgroup 2: the rest of the samples.

In this subgroup 2, two more blocks appeared:

Block 1: samples 6, 14 linked to very high permeability levels.

Block 2: The rest of the samples.

These groups were confirmed by a discriminant canonical analysis, in which the Mahalanobis distance of each sample was calculated with regard to the centroid of each group (Fig. 2 b). The analysis of permeability values in the range of small pores $(0.17-25 \mathrm{~nm})$ revealed separate samples 6,14 , and 23, which had the highest degree of permeability, while sample 6 for instance had the lowest proportion of $\mathrm{SiO}_{2}$, as well as highest quantities of $\mathrm{CaO}$ (Table 1). Furthermore, sample 23 was included in a mineralogical differentiated subgroup, as shown in Garzón et al. (2012).

With the chemical and mineralogical analysis made through XRF and XRD, respectively, a correlation can be seen (Table 3 ) for the 52 phyllite clays concerning the adsorption and desorption permeability values. Observed and predicted plots resulted from the statistical treatments of the data (Figs. 3 and 4). From these results, as previously expected, both chemical and mineralogical characteristics influenced this physical property because multiple-regression analysis enabled us to deduce such as a relationship. 


\section{Discussion}

Multivariate statistical analysis is a useful tool (Baxter, 1994; Mommsen, 2001) that introduces the importance of chemistry and chemometrics into classification of samples, for instance by linear discriminant analysis assuming that the variables are drawn from a population with multivariate normal distributions and determined variables have equal variances (García et al., 2005). Even more to find some correlation, if it is examined the influence of chemical and mineralogical characteristics of a group of samples on a physical property, such as permeability in this case. Permeability can be considered the most relevant physical property of phyllite clays according to their applications (Garzón et al., 2010; Garzón et al., 2015a, 2015b; Garzón et al., 2016). The application of multivariate statistical analysis was examined to study the possible correlations between the chemical and mineralogical characteristics of indirect permeability, but for small pores in the range $0.17-25 \mathrm{~nm}$. Thus, two correlations were found for adsorption and desorption permeability values.

The present results concerning multivariate statistical analysis demonstrated that the chemical as well as mineralogical characteristics correlated with indirect permeability. Two scenarios were considered: adsorption and desorption. A correlation was found between the permeability of small pores in the phyllite clays and the chemical composition data compiled by XRF. In the first approach (Fig. 3), the variable with the strongest influence on permeability (adsorption phase) was the chemical content of $\mathrm{K}_{2} \mathrm{O}$, which was associated with illite and feldspar (microcline), and the mineralogical variables with the strongest influence were quartz and chlorite $(P>0.05)$. The results of fitting a multiple linear regression model are presented in Figs. 3 and 4 at 90\% confidence level. Furthermore, the R-squared statistic indicated that the model as fitted explains a high percentage of the variability in ADS.

On the other hand, the highest probability value of the independent variables is $P=0.1175$, belonging to feldspar. Since this $P$-value is $>0.05$, the highest-order term was statistically significant at the $90 \%$ confidence level. Thus, it is not necessary to remove any variables from the model presented. In the case of desorption, this value was at the $90 \%$ of confidence level.

The discussion about the statistical conditions of the variables subjected to multivariate statistical analysis was checked for normality and homoscedasticity. For adsorption, according to the Kolmogorov-Smirnov statistical tests, the residuals would be normal because the $P$-value was higher than or equal to 0.05 , as reflected in Fig. $3(P=0.9867)$. In Fig. 3, homoscedasticity of the residuals was considered as follows. The Durbin-Watson statistical test was performed to determine whether 
there was any significant correlation based on the order in which they occurred in the data file. Since the Durbin-Watson values were $>1.4$ (in Fig. 3, $1.83821>1.4$ ), we deduced that there was no autocorrelation in the residuals and they were independent.

In the case of desorption, according to the Kolmogorov-Smirnov statistical tests, the residuals would be normal because the $P$-value was higher than or equal to 0.05 (in Fig. $4, P=0.3544>0.05$ ). The homoscedasticity of the residuals were found to be independent. In other words, on applying the Durbin-Watson statistical tests, the value was 2.57197 and we also deduced that there was not autocorrelation in the residuals because this value was higher than 1.4.

Finally, Table 3 included the multivariate correlation between paired variables. This Table of results shows the correlation of Pearson coefficients between two variables. The correlation range of the coefficients was between -1 and 1 . These coefficients measure the strength of the linear relation by a comparison of variables. The $P$-values indicate the statistical significance of the estimated correlation. Thus, P-values lower than 0.05 indicate significant correlations different of 0 with a confidence level of $95 \%$. For instance, according these results, the following pairs of variables had $P$-values lower than 0.05: ADS and $\mathrm{CaO}(\%), \mathrm{ADS}$ and Illite, ADS and Dolomite, ADS and Feldspar, ADS and Chlorite, ADS and I/S; Desop and Calcite.

\section{Summary and conclusions}

In this paper, several deposits of phyllite clays in the provinces of Almería and Granada (SE Spain) were studied. We report the results of applying a multivariate statistical analysis to the chemical analysis data of 52 samples determined by XRF, mineralogical analysis estimated by XRD, and indirect permeability.

First of all, the multivariate statistical analysis was used to study and classify the phyllite clay samples. Secondly, the chemical and mineralogical data were used to examine whether there was any correlation with indirect permeability. A correlation between chemical and mineralogical characteristics and permeability was found. Two regression equations were deduced in the present study considering a model which supports the correlation. The results of fitting the multiple linear 
regression model indicated that for adsorption and desorption, this value was lower (90\%), without any serious autocorrelation in the residuals according to the statistical test. The multivariate correlations between pairs of variables were provided.

The present results are valuable as a contribution to ascertain the physico-chemical characteristics and properties of phyllite clays of similar origin from several Spanish deposits. In particular, to develop waterproof types of compositions based on their applications working with the samples having the lowest permeability levels. Only through a better knowledge of the chemical and mineralogical composition and properties of the phyllite clays will it be possible to understand their traditional use for impermeabilization, to optimise them, and to propose new or improved applications.

\section{Acknowledgements}

The XRF analytical results were performed at CITIUS, which is kindly acknowledged. Thanks are extended to two anonymous reviewers and the Associated Editor Prof. Emilio Galán to improve the content and presentation of this paper. The financial support of Andalusia Regional Government (2014-2015) to this investigation through Research Groups AGR 107 and TEP 204 is acknowledged. 


\section{References}

Alcántara-Ayala, I., 1999. The Torvizcón, Spain, landslide of february 1996, the role of lithology in a semi-arid climate. Geophys. Int. 38, 1-3.

Azañón, J.M., Crespo-Blanc, A., García-Dueñas, V., Sánchez-Gómez, M., 1995. The Alpujárride complex structure and its contribution to the ESCI-Béticas2 deep seismic reflection profile interpretation (Alborán domain, Betic chain). Rev. Soc. Geol. Esp. 8, 491-501.

Barrett, E., Joyner, L., Halenda, P., 1951. The determination of pore volume and area distribution of porous substances I. Computations from Nitrogen Isotherms. J. Am. Chem. Soc. 73, 373-380.

Baxter,M.J., 1994. ExploratoryMultivariate Analysis in Archaeology. Edinburgh University Press, Edinburgh.

Biscaye, P.E., 1965. Mineralogy and sedimentation of recent deep-sea clay in the Atlantic Ocean and adjacent sea and oceans. Geol. Soc. Am. Bull. 76, 803-831.

Brunauer, S., Emmett, P.H., Teller, E., 1938. Adsorption of gases in multimolecular layers. J. Am. Chem. Soc. 60, 309-319.

Carretero, M.I., Pozo, M., Legido, J.L., Fernández-González, M.V., Delgado, R., Gómez, I., Armijo, F., Maraver, F., 2014. Assessment of three Spanish clays for their use in pelotherapy. Appl. Clay Sci. 99, 131-143.

Crespo-Blanc, A., 1995. Interference pattern of Miocene extensional systems in the Alpujarride complex (N of Sierra Nevada, Betic Cordillera). Geogaceta 17, 140-142.

Dolinar, B., Mišič, M., Trauner, L., 2007. Correlation between surface area and Atterberg limits of fine-grained soils. Clay Clay Miner. 55, 519-523.

Galán, E., Espinosa de los Monteros, J., 1974. In: de Cerámica y Vidrio, S.E. (Ed.), El caolín en España. Características, identificación y ensayos cerámicos. Industrias Gráficas España S.L., Madrid, Spain.

Galán, E., Mesa, J.M., A., M., Sánchez, C., 1995. Multivariate analysis as a tool for genetic approaches in clay mineralogy. Proc. 10th Int. Clay Conf., Adelaida, pp. 323-330.

Galán, E., Aparicio, P., González, I., Miras, A., 1998. Contribution ofmultivariate analysis to the correlation of some properties of kaolin with its mineralogical and chemical composition. Clay Miner. 33, 65-75.

García, R., Vigil de la Villa, R., Recio de la Rosa, P., Petit, M.D., Rucandio, M.I., 2005. Analytical and multivariate study of roman age architectural terracotta from northeast of Spain. Talanta 65, $861-868$. 
García-Bengochea, I., Lovell, C.W., Altschaeffl, A.G., 1979. Pore distribution and permeability of silty clays. J. Geotech. Eng. ASCE 105 (7), 839-856.

García-Ramos, G., González-García, F., Sánchez-Soto, P.J., Ruíz-Abrio, M.T., 1985. Propiedades refractarias y estudio de los productos obtenidos a partir de un conjunto de materiales silicoaluminosos españoles (I). Bol. Soc. Esp. Ceram. Vidrio 24, 67-79.

Garzón, E., García-Rodríguez, I.G., Ruiz-Conde, A., Sánchez-Soto, P.J., 2009a. Phyllites used as waterproofing layer materials for greenhouses crops in Spain: multivariate statistical analysis applied to their classification based on X-ray fluorescence analysis. XRay Spectrom. 38, 429438.

Garzón, E., García, I.G., Ruiz-Conde, A., Sánchez-Soto, P.J., 2009b. Aplicación de Sistemas de Información Geográfica (SIG) en la prospección y caracterización de materias primas de interés en Cerámica y Vidrio. Bol. Soc. Esp. Ceram. Vidrio 48, 39-42.

Garzón, E., Sánchez-Soto, P., Romero, E., 2010. Physical and geotechnical properties of clay phyllites. Appl. Clay Sci. 48, 307-318.

Garzón, E., Ruíz-Conde, A., Sánchez-Soto, P.J., 2012. Multivariate statistical analysis of phyllite samples based on chemical (XRF) and mineralogical data by XRD. Am. J. Anal. Chem. 3, 347363.

Garzón, E., Cano, M., O'Kelly, B.C., Sánchez-Soto, P.J., 2015a. Phyllite-clay cement composites having improved engineering properties and material applications. Appl. Clay Sci. 114, 229-233.

Garzón, E., Fernández, N., Gotor, F., Sánchez-Soto, P.J., 2015b. Procedimiento de preparación de un mortero impermeabilizante que emplea filitas, producto obtenido y su utilización. Patente Española (Spanish Patent) P201530329.

Garzón, E., Cano, M., O'Kelly, B.C., Sánchez-Soto, P.J., 2016. Effect of lime on stabilization of phyllite clays. Appl. Clay Sci. 329-334.

Gómez-Pugnaire, M.T., Sassi, F.P., Visona, D., 1978. Sobre la presencia de paragonita y pirofilita en las filitas del complejo Nevado-Filábride en la Sierra de Baza (Cordilleras Béticas, España). Bol. Geol. Min. 89, 468-474.

Jordán, M.M., Boix, A., Sanfeliú, T., De la Fuente, C., 1999. Firing transformations of cretaceous clays used in the manufacturing of ceramic tiles. Appl. Clay Sci. 14, 225-234.

Juang, C.H., Holtz, R.D., 1986a. Fabrics pore distribution and permeability of sandy soils. J. Geotech. Eng. Div. ASCE 112 (GT9), 855-868.

Juang, C.H., Holtz, R.D., 1986b. A probabilistic permeability model and the pore size density function. Int. J. Numer. Anal. Methods Geomech. 10, 543-553.

Lapierre, C., Leroueil, S., Locat, J., 1990. Mercury intrusion and permeability of Louiseville clay. Can. Geotech. J. 27, 761-773. 
Lonergan, L., Platt, J.P., 1995. The Malaguide-Alpujarride boundary: a major extensional contact in the internal zone of the eastern Betic Cordillera, SE Spain. J. Struct. Geol. 17, 1655-1671.

López, F., Galán, E.,Martín, J.L., 1971. Sobre lamineralogía y génesis de dos yacimientos de caolín en la provincia de Valencia. Estud. Geol. 27, 145-152.

Mesa López-Colmenar, J.M., 1986. Contribución al estudio mineralógico de las pizarras alumínicas (tierras blancas) del paleozoico de la provincia de Badajoz. Ph. D. Thesis. Universidad de Sevilla, Sevilla.

Mommsen, H., 2001. Provenance determination of pottery by trace element analysis: problems, solutions and applications. J. Radioanal. Nucl. Chem. 247 (3), 657-662.

Oliva-Urcia, B., Rahl, J.M., Schleicher, A.M., Parés, J.M., 2010. Correlation between the anisotropy of the magnetic susceptibility, strain ellipsoids and X-ray texture goniometry in phyllites from Crete, Greece. Tectonophysics 486, 120-131.

Oliveira, T.F., Beck,M.H., Escosteguy, P.V., Bortoluzzi, E.C., Modolo,M.L., 2015. The effect of the substitution of hydrated lime with phyllite on mortar quality. Appl. Clay Sci. 105-106, 113-117.

Parras, J., Sánchez-Jiménez, C., Rodas, M., Luque, F.J., 1996. Ceramic applications of middle Ordovician shales from central Spain. Appl. Clay Sci. 11, 25-41.

Ramamurthy, T., Venkatappa, R., Singh, J., 1993. Engineering behaviour of phyllites. Eng. Geol. 33, 209-225.

Sanz de Galdeano, C., 1990. Geologic evolution of the Betic Cordilleras in the western Mediterranean, Miocene to the present. Tectonophysics 172, 107-119.

Sanz de Galdeano, C., López-Garrido, A., 2014. Structure of the Sierra de Lujar (Alpujarride Complez, Betic Cordillera). Estud. Geol. 70 (1), 1-14.

$\underline{\text { Sanz de Galdeano, C., Andreo, B., García-Tortosa, F.J., López-Garrido, A.C., 2001. The Triassic }}$ palaeogeographic transition between the Alpujarride and Malaguide complexes. Betic-Rif internal zone (S Spain, N Morocco). Palaeogeogr. Palaeoclimatol. Palaeoecol. 167, 157-173.

Schultz, L.G., 1964. Quantitative interpretation of mineralogical composition from X-ray and chemical data for the Pierre Shale. US Geol. Surv. Prof. Pap. 391C (31pp.).

Sena, E.-D., Landsberger, S., Pena, J.T.,Wisseman, S., 1995. Analysis of ancient pottery from the Palatine hill in Rome. J. Radioanal. Nucl. Chem. 196 (2), 223-234.

Sing, S.W., Everett, D.H., Haul, R.A.,Moscow, L., Pierotti, R.A., Rouquerol, J., Siemieniewska, T., 1985. Reporting physisorption data for gas/solid systems with special reference to the determination of surface area and porosity. Pure Appl. Chem. 57, 603-619. 
Suárez, F.J., Navarro, F.A., Ortiz, A., 2005. Evolución histórica de la morfología Urbana y la tipología constructiva en el altiplano granadino, en: Actas del IV Congreso Nacional de Historia de la Construcción, Cádiz. pp. 1029-1038.

Valera, T.S., Ribeiro, A.P., Valenzuela-Díaz, F.R., Yoshiga, A., Ormanji,W., Toffoll, S.M., 2002. The effect of phyllite as a filler for PVC plastisols. Annual Technical Conference-Society of Plastics Engineers. 60, 3, pp. 3949-3953.

Vicol, T., 1990. Comportement hydraulique et mécanique d'un sol fin non saturé. Application à la modélisation, Thèse de doctorat. Ecole Nationale des Ponts et Chaussées, CERMES, Paris (France). 
TABLES:

Table 1. Chemical composition (wt.\%) of the 52 phyllite clay samples as determined by XRF.

\begin{tabular}{|c|c|c|c|c|c|c|c|c|c|c|}
\hline SAMPLE & $\mathrm{SiO}_{2}(\%)$ & $\mathrm{Al}_{2} \mathrm{O}_{3}(\%)$ & $\mathrm{Fe}_{2} \mathrm{O}_{3}(\%)$ & $\mathrm{MnO}(\%)$ & $\operatorname{MgO}(\%)$ & $\mathrm{CaO}(\%)$ & $\mathrm{Na}_{2} \mathrm{O}(\%)$ & $\mathrm{K}_{2} \mathrm{O}(\%)$ & $\mathrm{TiO}_{2}(\%)$ & $\mathrm{P}_{2} \mathrm{O}_{5}$ (\%) \\
\hline 1 & 49.62 & 26.72 & 8.6 & 0.07 & 1.72 & 3.26 & 2.29 & 3.72 & 1.09 & 0.13 \\
\hline 2 & 54.2 & 22.02 & 7.23 & 0.1 & 2.3 & 6.27 & 1.6 & 3.26 & 0.94 & 0.1 \\
\hline 3 & 49.78 & 26.88 & 8.24 & 0.09 & 1.65 & 4.38 & 2.05 & 3.9 & 1.02 & 0.14 \\
\hline 5 & 51.23 & 27.32 & 8.62 & 0.08 & 1.86 & 3.62 & 2.16 & 3.85 & 0.99 & 0.13 \\
\hline 6 & 44.22 & 19.82 & 5.76 & 0.07 & 2.74 & 14.24 & 1.66 & 2.57 & 0.86 & 0.07 \\
\hline 7 & 55.89 & 25.38 & 7.21 & 0.04 & 1.81 & 2.72 & 1.79 & 3.31 & 1 & 0.12 \\
\hline 8 & 53.49 & 25.08 & 8.03 & 0.08 & 1.62 & 3.93 & 2.38 & 3.6 & 0.98 & 0.08 \\
\hline 10 & 50.98 & 25.55 & 8.32 & 0.07 & 2.42 & 4.16 & 2.12 & 3.32 & 1.09 & 0.11 \\
\hline 11 & 51.06 & 25.34 & 8.99 & 0.1 & 2.68 & 3.67 & 2.35 & 3.55 & 1.1 & 0.14 \\
\hline 12 & 53.92 & 24.22 & 7.62 & 0.09 & 2.2 & 4.27 & 2.48 & 3.37 & 0.97 & 0.11 \\
\hline 13 & 52.42 & 23.27 & 7.64 & 0.09 & 2.96 & 5.22 & 1.71 & 3.61 & 1.03 & 0.1 \\
\hline 14 & 54.14 & 23.4 & 6.78 & 0.07 & 1.83 & 5.29 & 1.84 & 3.26 & 0.94 & 0.12 \\
\hline 15 & 48.74 & 23.49 & 8.11 & 0.1 & 3.53 & 5.27 & 1.91 & 3.54 & 0.95 & 0.11 \\
\hline 16 & 55.32 & 24.79 & 8.15 & 0.06 & 2.94 & 2.87 & 2.19 & 3.21 & 1.06 & 0.15 \\
\hline 17 & 50.77 & 26.36 & 8.74 & 0.08 & 2.99 & 3.95 & 2.58 & 3.71 & 1.04 & 0.12 \\
\hline 18 & 53.88 & 21.22 & 7.68 & 0.11 & 4.26 & 5.13 & 1.64 & 3.04 & 0.88 & 0.12 \\
\hline 21 & 49.51 & 24.25 & 8.15 & 0.09 & 2.95 & 5.35 & 2.13 & 3.87 & 1.13 & 0.1 \\
\hline 22 & 52.58 & 23.66 & 7.9 & 0.09 & 3.32 & 3.66 & 2.32 & 3.42 & 0.99 & 0.1 \\
\hline 23 & 52.03 & 24.77 & 7.47 & 0.06 & 2.63 & 4.15 & 2.49 & 3.47 & 0.96 & 0.11 \\
\hline 24 & 48.76 & 25.17 & 8.19 & 0.08 & 2.85 & 6.58 & 2.4 & 3.72 & 1.07 & 0.09 \\
\hline 25 & 52.56 & 25.72 & 7.71 & 0.08 & 2.59 & 3.73 & 2.7 & 3.68 & 1 & 0.11 \\
\hline 26 & 56.68 & 22.58 & 7.65 & 0.07 & 3.2 & 4.16 & 1.8 & 3.34 & 1.03 & 0.14 \\
\hline 27 & 55.18 & 23.72 & 8.47 & 0.06 & 2.32 & 2.98 & 1.7 & 3.82 & 1.01 & 0.14 \\
\hline 28 & 59.59 & 24.1 & 7.46 & 0.07 & 2.44 & 2.19 & 1.83 & 3.58 & 0.91 & 0.15 \\
\hline 29 & 59.55 & 23.82 & 6.55 & 0.06 & 1.39 & 2.1 & 1.98 & 4.02 & 1.03 & 0.11 \\
\hline 30 & 58.78 & 24.49 & 7.12 & 0.06 & 1.56 & 2.5 & 2.11 & 3.94 & 0.98 & 0.11 \\
\hline 31 & 48.79 & 24.74 & 8.68 & 0.12 & 3.28 & 5.75 & 2.9 & 3.49 & 1.04 & 0.11 \\
\hline 32 & 54.69 & 21.51 & 7.37 & 0.1 & 3.12 & 6.02 & 1.76 & 3.18 & 0.9 & 0.11 \\
\hline 33 & 54.87 & 22.91 & 6.72 & 0.08 & 2.46 & 5.33 & 1.52 & 3.48 & 0.9 & 0.13 \\
\hline 34 & 51.32 & 22.69 & 7.05 & 0.11 & 3.17 & 7.33 & 1.24 & 3.78 & 0.86 & 0.1 \\
\hline 35 & 53.17 & 23.62 & 6.38 & 0.1 & 2.66 & 6.53 & 1.42 & 3.72 & 0.89 & 0.11 \\
\hline 36 & 50.36 & 22.01 & 6.48 & 0.09 & 2.02 & 5.68 & 1.6 & 3.09 & 0.92 & 0.1 \\
\hline 37 & 54.38 & 23.25 & 7.57 & 0.1 & 3.23 & 4.74 & 1.66 & 3.34 & 0.89 & 0.11 \\
\hline 38 & 54.02 & 25.61 & 7.81 & 0.07 & 1.92 & 3.37 & 1.39 & 5.33 & 0.95 & 0.12 \\
\hline 39 & 58.13 & 22.9 & 8.88 & 0.11 & 1.56 & 1.83 & 1.18 & 4.48 & 0.88 & 0.12 \\
\hline 41 & 54.51 & 17.99 & 6.63 & 0.1 & 3.47 & 6.7 & 0.88 & 2.45 & 0.77 & 0.11 \\
\hline 42 & 57.09 & 19.46 & 6.17 & 0.1 & 2.03 & 8.27 & 1.33 & 2.85 & 0.8 & 0.14 \\
\hline 43 & 64.94 & 19.07 & 5.95 & 0.07 & 1.29 & 1.84 & 0.9 & 2.56 & 0.82 & 0.12 \\
\hline 44 & 66.26 & 18.44 & 5.02 & 0.06 & 1.15 & 0.89 & 1.11 & 2.52 & 0.72 & 0.12 \\
\hline 45 & 66.61 & 18.49 & 4.39 & 0.04 & 1.03 & 0.42 & 1.49 & 2.64 & 0.68 & 0.14 \\
\hline 46 & 64.19 & 19.61 & 5.92 & 0.06 & 1.2 & 0.96 & 1.12 & 2.8 & 0.81 & 0.12 \\
\hline 47 & 61.19 & 23.59 & 6.28 & 0.06 & 1.27 & 0.22 & 1.2 & 3.57 & 0.75 & 0.14 \\
\hline 48 & 59.73 & 19.94 & 6.2 & 0.19 & 0.74 & 1.5 & 1.2 & 3.29 & 0.93 & 0.13 \\
\hline 49 & 55.99 & 24.63 & 8.02 & 0.08 & 1.67 & 0.41 & 2.86 & 3.69 & 0.95 & 0.16 \\
\hline 50 & 62.16 & 19.93 & 6.27 & 0.06 & 1.27 & 0.29 & 1.1 & 2.99 & 0.68 & 0.13 \\
\hline 51 & 59.04 & 23.72 & 7.83 & 0.11 & 0.89 & 0.38 & 1.35 & 3.51 & 0.97 & 0.15 \\
\hline 52 & 59.44 & 24 & 6.42 & 0.08 & 0.71 & 1.18 & 1.39 & 3.56 & 0.86 & 0.15 \\
\hline
\end{tabular}


Table 2. Mineralogical composition of the 52 phyllite samples as determined by XRD (wt.\%) and indirect permeability obtained in the adsorption (ADS) and desorption (DESOP) phases.

\begin{tabular}{|c|c|c|c|c|c|c|c|c|c|c|c|c|c|c|c|c|c|c|c|c|c|}
\hline \multirow[t]{2}{*}{ ID } & \multirow[t]{2}{*}{ I } & \multirow[t]{2}{*}{ Do } & \multirow[t]{2}{*}{$\mathrm{Fd}$} & \multirow[t]{2}{*}{$\mathrm{Cl}$} & \multirow[t]{2}{*}{$\mathrm{F}$} & \multirow[t]{2}{*}{$\mathrm{Qz}$} & \multirow[t]{2}{*}{$\mathrm{Ca}$} & \multirow[t]{2}{*}{$\mathrm{I} / \mathrm{S}$} & \multicolumn{2}{|c|}{ Permeability } & \multirow[t]{2}{*}{ ID } & \multirow[t]{2}{*}{ I } & \multirow[t]{2}{*}{ Do } & \multirow[t]{2}{*}{$\mathrm{Fd}$} & \multirow[t]{2}{*}{$\mathrm{Cl}$} & \multirow[t]{2}{*}{$\mathrm{F}$} & \multirow[t]{2}{*}{$\mathrm{Qz}$} & \multirow[t]{2}{*}{$\mathrm{Ca}$} & \multirow[t]{2}{*}{$\mathrm{I} / \mathrm{S}$} & \multicolumn{2}{|l|}{ Permeability } \\
\hline & & & & & & & & & $\begin{array}{l}\text { ADS } \\
(\mathrm{m} / \mathrm{s})\end{array}$ & $\begin{array}{l}\text { DESOP } \\
(\mathrm{m} / \mathrm{s})\end{array}$ & & & & & & & & & & $\begin{array}{l}\text { ADS } \\
(\mathrm{m} / \mathrm{s})\end{array}$ & $\begin{array}{l}\text { DESOP } \\
(\mathrm{m} / \mathrm{s})\end{array}$ \\
\hline 1 & 10 & 16 & 16 & 6 & 15 & 37 & $<2$ & $<2$ & $8.25 E-13$ & $1.92 \mathrm{E}-13$ & 27 & 15 & ND & 10 & 15 & 3 & 52 & 5 & $<2$ & $5.13 E-13$ & $1.92 \mathrm{E}-13$ \\
\hline 2 & 11 & 30 & 5 & 6 & 5 & 43 & $<2$ & $<2$ & $9.65 \mathrm{E}-13$ & $2.26 \mathrm{E}-13$ & 28 & 15 & 5 & 11 & 7 & 6 & 56 & ND & $<2$ & $7.05 \mathrm{E}-13$ & $2.09 \mathrm{E}-13$ \\
\hline 3 & 13 & 32 & 3 & 4 & 6 & 42 & ND & $<2$ & $6.03 E-13$ & $1.18 \mathrm{E}-13$ & 29 & 12 & 7 & 10 & 5 & 7 & 59 & $<2$ & $<2$ & $4.05 \mathrm{E}-13$ & $9.02 \mathrm{E}-14$ \\
\hline 4 & 16 & 31 & 4 & 4 & 5 & 40 & ND & $<2$ & $1.06 \mathrm{E}-12$ & $2.69 \mathrm{E}-13$ & 30 & 13 & 10 & 12 & 3 & 5 & 57 & $<2$ & ND & $4.5 \mathrm{E}-13$ & $1.25 \mathrm{E}-13$ \\
\hline 5 & 14 & 26 & 4 & 3 & 6 & 47 & $<2$ & $<2$ & $7.81 \mathrm{E}-13$ & $1.99 \mathrm{E}-13$ & 31 & 20 & 10 & 15 & 10 & 8 & 37 & $<2$ & $<2$ & $3.82 \mathrm{E}-13$ & $1.83 \mathrm{E}-13$ \\
\hline 6 & 15 & 30 & 5 & 4 & 5 & 41 & ND & $<2$ & $1.28 \mathrm{E}-12$ & $2.78 \mathrm{E}-13$ & 32 & 15 & 15 & 10 & 5 & 5 & 45 & 5 & ND & $5.7 \mathrm{E}-13$ & $4.16 \mathrm{E}-13$ \\
\hline 7 & 15 & 5 & 10 & 5 & 5 & 55 & $<2$ & $<2$ & $9.79 \mathrm{E}-13$ & $2.19 \mathrm{E}-13$ & 33 & 7 & 10 & 5 & 5 & 3 & 70 & $<2$ & $<2$ & $6.14 \mathrm{E}-13$ & $2.25 \mathrm{E}-13$ \\
\hline 8 & 16 & 10 & 9 & 5 & 10 & 50 & $<2$ & ND & $5.91 \mathrm{E}-13$ & $3.99 \mathrm{E}-13$ & 34 & 15 & 20 & 8 & 5 & 5 & 47 & $<2$ & $<2$ & $4.78 \mathrm{E}-13$ & $3.46 \mathrm{E}-13$ \\
\hline 9 & 15 & 12 & 10 & 5 & 11 & 47 & ND & ND & $5.15 \mathrm{E}-13$ & $1.14 \mathrm{E}-13$ & 35 & 12 & 23 & 6 & 4 & 5 & 50 & $<2$ & ND & $4.53 \mathrm{E}-13$ & $1.42 \mathrm{E}-13$ \\
\hline 10 & 15 & 8 & 10 & 7 & 8 & 52 & $<2$ & ND & $9.16 \mathrm{E}-13$ & $7.3 E-13$ & 36 & 13 & 14 & 10 & 6 & 4 & 53 & ND & ND & $3.21 \mathrm{E}-13$ & $1.42 \mathrm{E}-13$ \\
\hline 11 & 25 & 3 & 15 & 18 & 7 & 32 & $<2$ & ND & $3.79 E-13$ & $9.91 E-14$ & 37 & 10 & 12 & 8 & 7 & 6 & 57 & $<2$ & $<2$ & $8.24 \mathrm{E}-13$ & $3.42 \mathrm{E}-13$ \\
\hline 12 & 18 & 12 & 9 & 6 & 10 & 45 & ND & ND & $4.71 \mathrm{E}-13$ & $9.14 \mathrm{E}-14$ & 38 & 22 & 10 & 12 & 3 & 8 & 45 & $<2$ & $<2$ & $4.84 \mathrm{E}-13$ & $1.63 \mathrm{E}-13$ \\
\hline 13 & 14 & 7 & 10 & 10 & 6 & 53 & $<2$ & $<2$ & $7.45 \mathrm{E}-13$ & $1.76 \mathrm{E}-13$ & 39 & 13 & 6 & 10 & 2 & 8 & 61 & ND & $<2$ & $5.99 \mathrm{E}-13$ & $2.15 E-13$ \\
\hline 14 & 10 & 10 & 7 & 4 & 7 & 62 & $<2$ & $<2$ & $1.33 \mathrm{E}-12$ & $3.45 \mathrm{E}-13$ & 40 & 9 & 22 & 4 & 8 & 3 & 54 & $<2$ & $<2$ & $8.69 E-13$ & $4.08 \mathrm{E}-13$ \\
\hline 15 & 16 & 15 & 7 & 8 & 5 & 49 & ND & $<2$ & $8.01 \mathrm{E}-13$ & $1.93 \mathrm{E}-13$ & 41 & 7 & 8 & 3 & 8 & 2 & 72 & $<2$ & $<2$ & $6.37 \mathrm{E}-13$ & $2.48 \mathrm{E}-13$ \\
\hline 16 & 15 & 3 & 6 & 12 & 8 & 56 & $<2$ & $<2$ & $5.36 \mathrm{E}-13$ & $9.92 \mathrm{E}-14$ & 42 & 8 & 6 & 5 & 4 & 2 & 67 & 8 & $<2$ & $8.4 \mathrm{E}-13$ & $4.89 \mathrm{E}-13$ \\
\hline 17 & 20 & 2 & 10 & 10 & 10 & 48 & $<2$ & $<2$ & $7.45 E-13$ & $1.6 \mathrm{E}-13$ & 43 & 6 & ND & 4 & 5 & 2 & 83 & $<2$ & $<2$ & $6.63 \mathrm{E}-13$ & $2.12 \mathrm{E}-13$ \\
\hline 18 & 8 & 5 & 10 & 8 & 5 & 64 & $<2$ & $<2$ & $5.68 \mathrm{E}-13$ & $1.09 \mathrm{E}-13$ & 44 & 5 & ND & 4 & 4 & 2 & 85 & $<2$ & $<2$ & $6.15 E-13$ & $3.28 \mathrm{E}-13$ \\
\hline 19 & 10 & 5 & 5 & 5 & 5 & 70 & ND & $<2$ & $7.42 \mathrm{E}-13$ & $2.3 E-13$ & 45 & 6 & ND & 4 & 6 & 2 & 82 & $<2$ & $<2$ & $4.65 \mathrm{E}-13$ & $1.21 \mathrm{E}-13$ \\
\hline 20 & 16 & 11 & 12 & 7 & 6 & 48 & $<2$ & $<2$ & $4.03 E-13$ & $8.85 E-14$ & 46 & 5 & ND & 5 & 5 & 2 & 83 & $<2$ & $<2$ & $5.97 \mathrm{E}-13$ & $3.19 \mathrm{E}-13$ \\
\hline 21 & 20 & 5 & 18 & 15 & 7 & 35 & ND & $<2$ & $6.07 \mathrm{E}-13$ & $1.34 \mathrm{E}-13$ & 47 & 18 & ND & 6 & 12 & 2 & 62 & $<2$ & $<2$ & $8.87 E-13$ & $6.38 \mathrm{E}-13$ \\
\hline 22 & 18 & 6 & 15 & 15 & 8 & 38 & ND & $<2$ & $5.99 \mathrm{E}-13$ & $1.31 \mathrm{E}-13$ & 48 & 23 & 2 & 8 & 6 & 2 & 57 & 2 & ND & $4.89 \mathrm{E}-13$ & $1.81 \mathrm{E}-13$ \\
\hline 23 & 8 & 20 & 7 & 5 & 10 & 45 & $<2$ & $<2$ & $1.24 \mathrm{E}-12$ & $5.64 \mathrm{E}-13$ & 49 & 22 & ND & 8 & 20 & ND & 50 & ND & $<2$ & $3.66 \mathrm{E}-13$ & $1.04 \mathrm{E}-13$ \\
\hline 24 & 28 & 8 & 17 & 11 & 6 & 30 & $<2$ & $<2$ & $4.54 \mathrm{E}-13$ & $8.63 E-14$ & 50 & 23 & ND & 5 & 23 & 2 & 47 & ND & $<2$ & $4.02 \mathrm{E}-13$ & $5.17 \mathrm{E}-14$ \\
\hline 25 & 12 & 5 & 10 & 5 & 5 & 63 & ND & $<2$ & $4.7 \mathrm{E}-13$ & $1.71 \mathrm{E}-13$ & 51 & 25 & ND & 11 & 12 & 3 & 49 & ND & ND & $5.52 \mathrm{E}-13$ & $3.66 \mathrm{E}-13$ \\
\hline 26 & 10 & 5 & 10 & 10 & 7 & 58 & ND & $<2$ & $8.54 \mathrm{E}-13$ & $3.66 \mathrm{E}-13$ & 52 & 25 & ND & 10 & 8 & 2 & 53 & 2 & ND & $5.52 \mathrm{E}-13$ & $3.88 \mathrm{E}-13$ \\
\hline
\end{tabular}

Note: $\mathrm{ID}=$ Samples, $\mathrm{I}=$ Illite, $\mathrm{Do}=$ Dolomite, $\mathrm{Fd}=$ Feldspar, $\mathrm{Cl}=$ Chlorite, $\mathrm{F}=$ Iron oxide, $\mathrm{Qz}=\mathrm{Quartz}, \mathrm{Ca}=$ Calcite, $\mathrm{I} / \mathrm{S}=\mathrm{Interstratified}, \mathrm{ND}=$ non detected, $\mathrm{ADS}=\mathrm{Adsorption}, \mathrm{DESOP}$ $=$ Desorption. 
Table 3. Multivariate correlation.

\begin{tabular}{|c|c|c|}
\hline Variable & ADS & Desop \\
\hline \multicolumn{3}{|l|}{$\mathrm{SiO}_{2}(\%)$} \\
\hline Coefficients of correlation & -0.1574 & 0.1335 \\
\hline$P$-value & 0.2651 & 0.3455 \\
\hline \multicolumn{3}{|l|}{$\mathrm{Al}_{2} \mathrm{O}_{3}(\%)$} \\
\hline Coefficients of correlation & -0.0037 & -0.1128 \\
\hline$P$-value & 0.9790 & 0.4259 \\
\hline \multicolumn{3}{|l|}{$\mathrm{Fe}_{2} \mathrm{O}_{3}(\%)$} \\
\hline Coefficients of correlation & -0.0834 & -0.1592 \\
\hline$P$-value & 0.5564 & 0.2596 \\
\hline \multicolumn{3}{|l|}{$\mathrm{MnO}(\%)$} \\
\hline Coefficients of correlation & -0.2177 & -0.1056 \\
\hline$P$-value & 0.1211 & 0.4563 \\
\hline \multicolumn{3}{|l|}{$\operatorname{MgO}(\%)$} \\
\hline Coefficients of correlation & 0.0682 & -0.0887 \\
\hline$P$-value & 0.6311 & 0.5315 \\
\hline \multicolumn{3}{|l|}{$\mathrm{CaO}(\%)$} \\
\hline Coefficients of correlation & 0.3374 & 0.0612 \\
\hline$P$-value & 0.0145 & 0.6663 \\
\hline \multicolumn{3}{|l|}{$\mathrm{Na}_{2} \mathrm{O}(\%)$} \\
\hline Coefficients of correlation & -0.0246 & -0.2348 \\
\hline$P$-value & 0.8624 & 0.0938 \\
\hline \multicolumn{3}{|l|}{$\mathrm{K}_{2} \mathrm{O}(\%)$} \\
\hline Coefficients of correlation & -0.2203 & -0.1884 \\
\hline$P$-value & 0.1166 & 0.1810 \\
\hline \multicolumn{3}{|l|}{$\mathrm{TiO}_{2}(\%)$} \\
\hline Coefficients of correlation & -0.0353 & -0.2227 \\
\hline$P$-value & 0.8040 & 0.1125 \\
\hline \multicolumn{3}{|l|}{$\mathrm{P}_{2} \mathrm{O}_{5}(\%)$} \\
\hline Coefficients of correlation & -0.1394 & 0.0501 \\
\hline$P$-value & 0.3245 & 0.7245 \\
\hline \multicolumn{3}{|l|}{ I } \\
\hline Coefficients of correlation & -0.3285 & -0.2098 \\
\hline$P$-value & 0.0174 & 0.1355 \\
\hline \multicolumn{3}{|l|}{ Do } \\
\hline Coefficients of correlation & 0.3941 & 0.0424 \\
\hline$P$-value & 0.0038 & 0.7655 \\
\hline \multicolumn{3}{|l|}{$\mathrm{Fd}$} \\
\hline Coefficients of correlation & -0.3191 & -0.2387 \\
\hline$P$-value & 0.0211 & 0.0884 \\
\hline \multicolumn{3}{|l|}{$\mathrm{Cl}$} \\
\hline Coefficients of correlation & -0.2977 & -0.2180 \\
\hline$P$-value & 0.0321 & 0.1205 \\
\hline \multicolumn{3}{|l|}{$\mathrm{F}$} \\
\hline Coefficients of correlation & 0.1511 & -0.0870 \\
\hline$P$-value & 0.2850 & 0.5396 \\
\hline \multicolumn{3}{|l|}{$\mathrm{Qz}$} \\
\hline Coefficients of correlation & 0.0070 & 0.1839 \\
\hline$P$-value & 0.9608 & 0.1920 \\
\hline \multicolumn{3}{|l|}{$\mathrm{Ca}$} \\
\hline Coefficients of correlation & 0.0478 & 0.3287 \\
\hline$P$-value & 0.7367 & 0.0173 \\
\hline \multicolumn{3}{|l|}{$\mathrm{I} / \mathrm{S}$} \\
\hline Coefficients of correlation & 0.3164 & -0.1022 \\
\hline$P$-value & 0.0223 & 0.4712 \\
\hline
\end{tabular}

Note: $\mathrm{ID}=$ Samples, $\mathrm{I}=$ Illite, Do $=$ Dolomite, $\mathrm{Fd}=$ Feldspar, $\mathrm{Cl}=$ Chlorite, $\mathrm{F}=$ Iron oxide, $\mathrm{Qz}=$ Quartz, $\mathrm{Ca}=$ Calcite, $\mathrm{I} / \mathrm{S}=$ Interstratified, $\mathrm{ADS}=$ Adsorption, Desop $=$ Desorption. 


\section{FIGURES:}

Figure 1. Identification (ID) and localization by GPS of the samples.

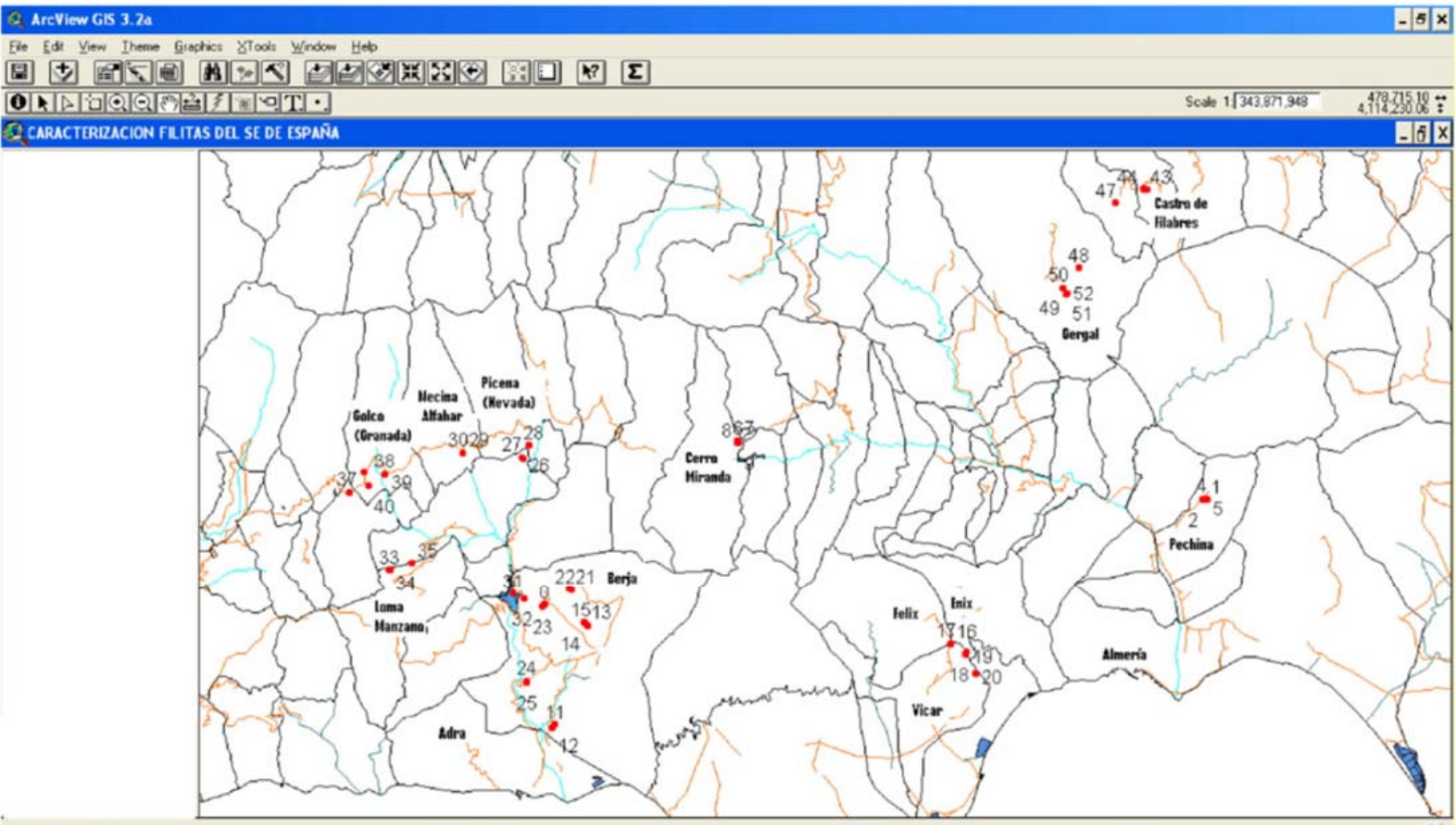




\begin{tabular}{|c|c|c|c|c|c|c|c|c|c|}
\hline ID & Coordinate $\mathrm{X}$ & Coordinate $Y$ & Altitude & Localization & ID & Coordinate $\mathbf{X}$ & Coordinate $\mathrm{Y}$ & Altitude & Localization \\
\hline 1 & 553311 & 4090277 & 386 & Sierra Alhamilla -Almeria & 27 & 498523 & 4093685 & 673 & Loma Palomares - Granada \\
\hline 2 & 553278 & 4090308 & 389 & Sierra Alhamilla -Almeria & 28 & 499083 & 4094683 & 809 & Picena-Granada \\
\hline 3 & 553294 & 4090271 & 387 & Sierra Alhamilla -Almeria & 29 & 493813 & 4094054 & 775 & Mecina Afahar -Granada \\
\hline 4 & 553100 & 4090334 & 408 & Sierra Alhamilla -Almeria & 30 & 493800 & 4094070 & 778 & Mecina Afahar-Granada \\
\hline 5 & 553475 & 4090268 & 368 & Sierra Alhamilla -Almeria & 31 & 497849 & 4082751 & 353 & Pantano de Beninar -Almeria \\
\hline 6 & 515864 & 4095033 & 972 & Sierra Alhamilla -Almeria & 32 & 498743 & 4082262 & 358 & Pantano de Beninar -Almeria \\
\hline 7 & 515867 & 4094997 & 986 & Cerro Miranda-Almeria & 33 & 487919 & 4084640 & 602 & Loma del Manzano - Granada \\
\hline 8 & 515834 & 4094835 & 989 & Cerro Miranda -Almeria & 34 & 487981 & 4084641 & 605 & Loma del Manzano - Granada \\
\hline 9 & 515868 & 4094834 & 997 & Cerro Miranda -Almeria & 35 & 489716 & 4085213 & 629 & Loma del Manzano -Granada \\
\hline 10 & 515891 & 4094840 & 1001 & Cerro Miranda -Almeria & 36 & 489686 & 4085232 & 631 & Loma del Manzano - Granada \\
\hline 11 & 501169 & 4072174 & 238 & Cerro Miranda -Almeria & 37 & 484715 & 4090880 & 1200 & $\begin{array}{l}\text { Cra. Berchules a Mecina } \\
\text { Bombaror-Granada }\end{array}$ \\
\hline 12 & 500986 & 4071956 & 234 & Alto del Cerrón-Almeria & 38 & 487553 & 4092332 & 1120 & Golco -Granada \\
\hline 13 & 503788 & 4080132 & 356 & $\begin{array}{l}\text { Penaurodada } \\
\text { (Berja)-Almeria }\end{array}$ & 39 & 487578 & 4092315 & 1112 & Golco - Granada \\
\hline 14 & 503613 & 4080312 & 363 & Peñarrodada (Berja)-Almeria & 40 & 486255 & 4091387 & 1120 & Golco-Granada \\
\hline 15 & 503596 & 4080372 & 377 & $\begin{array}{l}\text { Peñarrodada } \\
\text { (Berja)-Almeria }\end{array}$ & 41 & 486269 & 4091394 & 1122 & Golco-Granada \\
\hline 16 & 532932 & 4078647 & 529 & $\begin{array}{l}\text { Rambla Hortichuelas (Enix)- } \\
\text { Almeria }\end{array}$ & 42 & 485903 & 4092520 & 1220 & Mecina Bombarón-Granada \\
\hline 17 & 532919 & 4078671 & 531 & $\begin{array}{l}\text { Rambla Hortichuelas (Enix)- } \\
\text { Almeria }\end{array}$ & 43 & 548715 & 4115214 & 1130 & Castro de Filabres - Almeria \\
\hline 18 & 534133 & 4077874 & 387 & $\begin{array}{l}\text { Rambla Hortichuelas (Enix)- } \\
\text { Almeria }\end{array}$ & 44 & 548430 & 4115235 & 1149 & Castro de Filabres- Almeria \\
\hline 19 & 534206 & 4077978 & 358 & $\begin{array}{l}\text { Rambla Hortichuelas (Enix)- } \\
\text { Almeria }\end{array}$ & 45 & 548442 & 4115233 & 1147 & Castro de Filabres-Almeria \\
\hline 20 & 534925 & 4076316 & 207 & $\begin{array}{l}\text { Rambla Hortichuelas (Enix)- } \\
\text { Almeria }\end{array}$ & 46 & 548443 & 4115338 & 1178 & Castro de Filabres- Almeria \\
\hline 21 & 502551 & 4083060 & 546 & El Cid (Berja) -Almeria & 47 & 546145 & 4114144 & 1067 & Olula de Castro- Almeria \\
\hline 22 & 502382 & 4083101 & 559 & El Cid (Berja)-Almeria & 48 & 543239 & 4108948 & 887 & Gergal- Almeria \\
\hline 23 & 500220 & 4081617 & 478 & $\begin{array}{l}\text { Cortijada de Rodriguez (Berja)- } \\
\text { Almeria }\end{array}$ & 49 & 541941 & 4107295 & 742 & Gergal-Almeria \\
\hline 24 & 498904 & 4075698 & 265 & Rio Grande -Almeria & 50 & 541922 & 4107358 & 742 & Gergal- Almeria \\
\hline 25 & 498898 & 4075577 & 253 & Rio Grande -Almeria & 51 & 542183 & 4106782 & 798 & Gergal- Almeria \\
\hline 26 & 498647 & 4093609 & 658 & Loma Palomares-Granada & 52 & 542278 & 4106841 & 803 & Gergal- Almeria \\
\hline
\end{tabular}


Figure 2. Permeability results obtained by statistical treatment of the data: a) dendrogram and b) discriminant analysis.

\section{Dendrogram}

Nearest Neighbor Method,Squared Euclidean

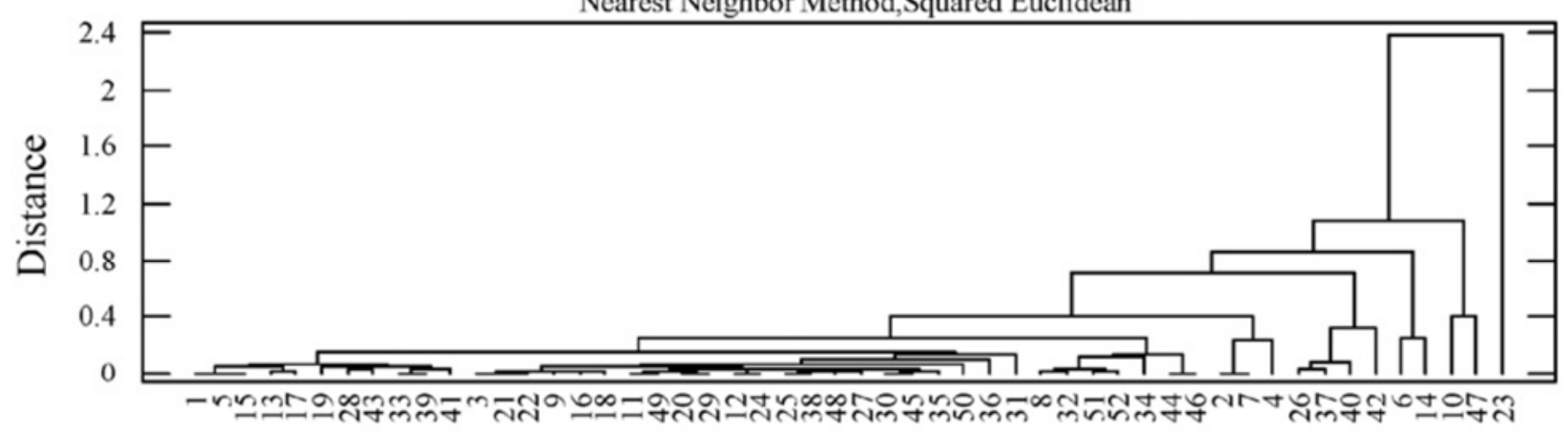

a)

\section{Plot of Canonical Variables \#1}

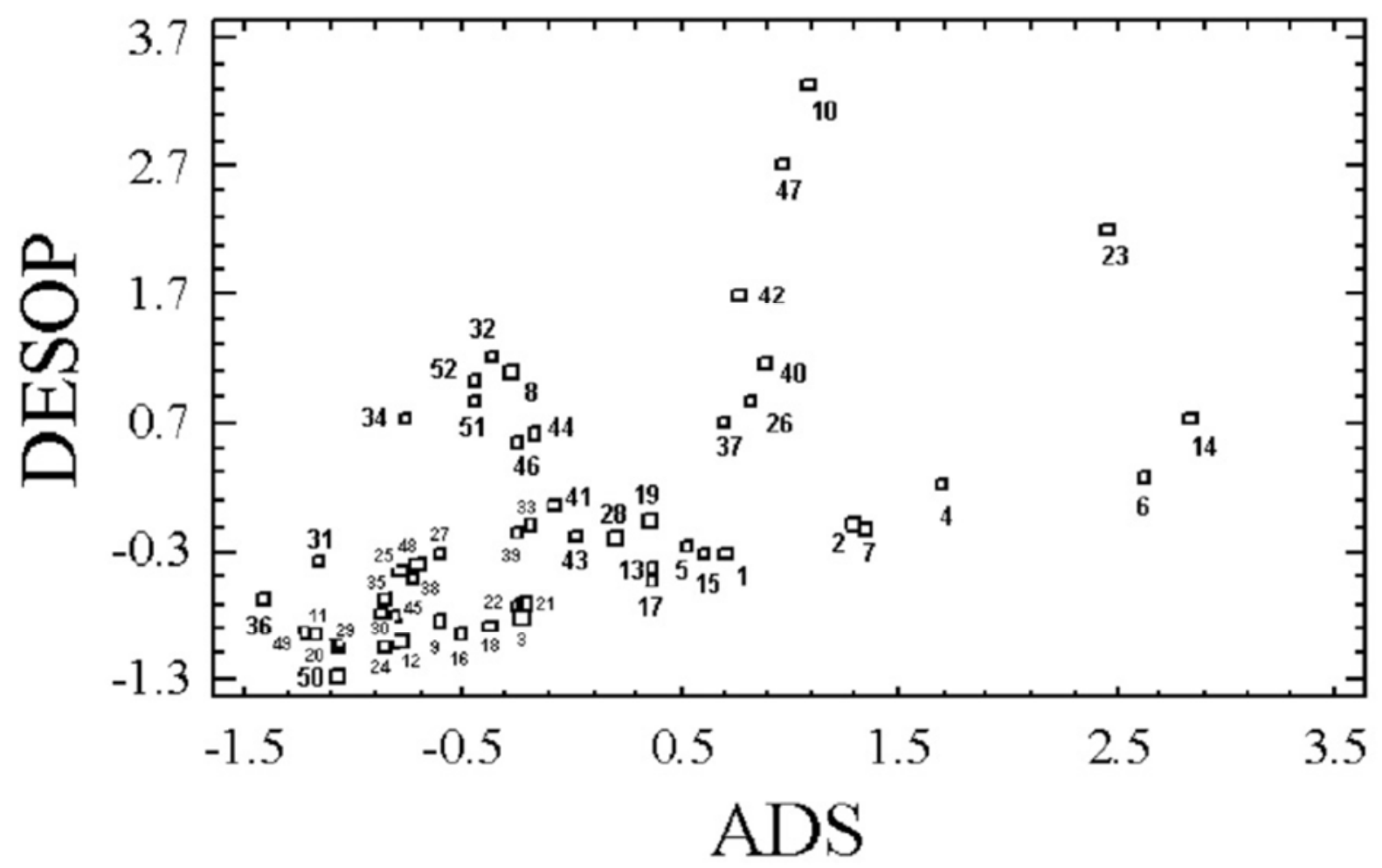

b) 
Figure 3. Multiple Regression Analysis of permeability (Adsorption).

\section{Plot of ADS}

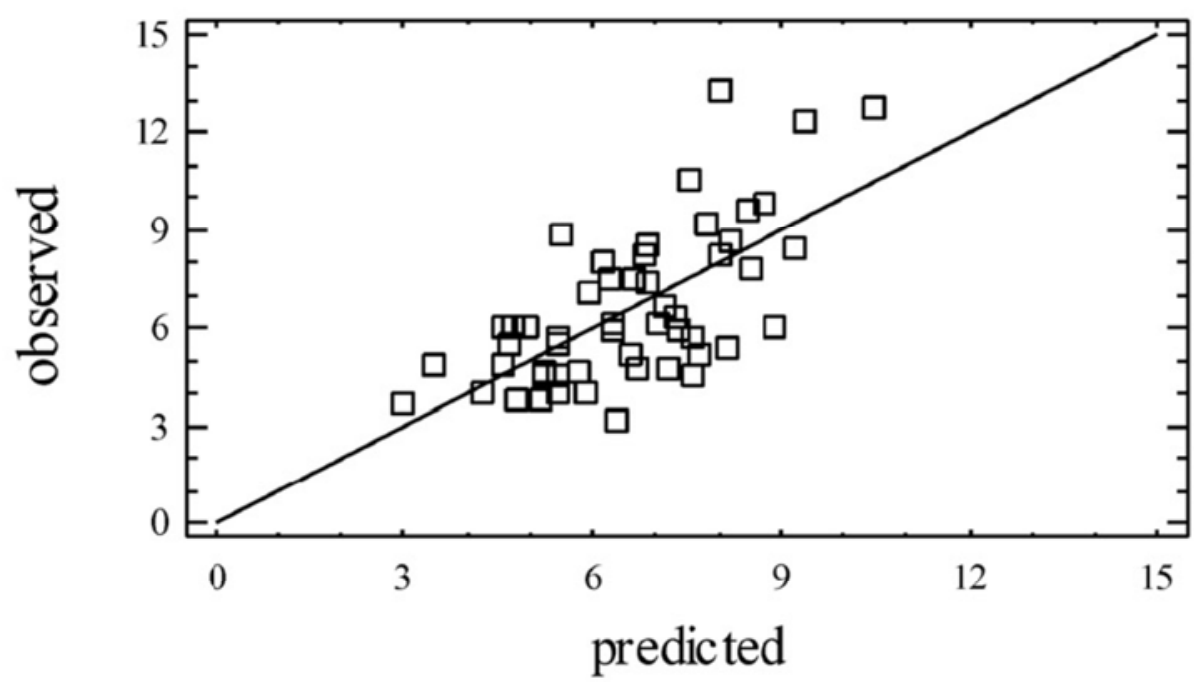

$\mathrm{ADS}=22,5117 \mathrm{E}-13+0,0903362 \mathrm{E}-13^{*} \mathrm{SiO}_{2}+0,362109 \mathrm{E}-13^{*} \mathrm{Al}_{2} \mathrm{O}_{3}+0,148209 \mathrm{E}-13^{*} \mathrm{Fe}_{2} \mathrm{O}_{3}+0,342614 \mathrm{E}-13^{*} \mathrm{CaO}-1,6964 \mathrm{E}-13^{*} \mathrm{~K} 2 \mathrm{O}-0,187538 \mathrm{E}-13^{*} \mathrm{MgO}-16,8568 \mathrm{E}-$ $13^{*} \mathrm{MnO}-1,14811 \mathrm{E}-13^{*} \mathrm{Na}_{2} \mathrm{O}+0,709762 \mathrm{E}-13^{*} \mathrm{P}_{2} \mathrm{O}_{5}+2,61813 \mathrm{E}-13^{*} \mathrm{TiO}_{2}-0,24001 \mathrm{E}-13^{*} \mathrm{Cl}-0,201786 \mathrm{E}-13^{*} \mathrm{Do}-0,0224 \mathrm{E}-13 * \mathrm{f}-0,424738 \mathrm{E}-13^{*} \mathrm{Fd}-0,25495 \mathrm{E}-13^{*} \mathrm{I}-$ $0,248147 \mathrm{E}-13^{*} \mathrm{Qz}$

\begin{tabular}{|c|c|}
\hline \multicolumn{2}{|c|}{ Multiple Regression Analysis } \\
\hline \multicolumn{2}{|c|}{ Dependent variable: ADS } \\
\hline \multicolumn{2}{|c|}{ Selection variable: Samples } \\
\hline Parameter & P-Value \\
\hline Constant & 0,4520 \\
\hline $\mathrm{SiO}_{2}$ & 0,6953 \\
\hline $\mathrm{Al}_{2} \mathrm{O}_{3}$ & 0,4869 \\
\hline $\mathrm{Fe}_{2} \mathrm{O}_{3}$ & 0,8446 \\
\hline $\mathrm{CaO}$ & 0,4090 \\
\hline $\mathrm{K}_{2} \mathrm{O}$ & 0,1490 \\
\hline $\mathrm{MgO}$ & 0,7907 \\
\hline $\mathrm{MnO}$ & 0,3679 \\
\hline $\mathrm{Na}_{2} \mathrm{O}$ & 0,2696 \\
\hline $\mathrm{P}_{2} \mathrm{O}_{5}$ & 0,9783 \\
\hline $\mathrm{TiO}_{2}$ & 0,6976 \\
\hline $\mathrm{Cl}$ & 0,2961 \\
\hline Do & 0,3135 \\
\hline $\mathrm{F}$ & 0,9300 \\
\hline Fd & 0,1175 \\
\hline I & 0,2580 \\
\hline Qz & 0,2089 \\
\hline R-squared & 44,13 percent \\
\hline \multicolumn{2}{|c|}{ Homoscedasticity residuals } \\
\hline Durbin-Watson statistic & $1,83821>1,4$ \\
\hline \multicolumn{2}{|c|}{ Normality residuals } \\
\hline \multirow{2}{*}{$\begin{array}{l}\text { Kolmogorov-Smirnov } \\
\text { Statistic DPLUS }\end{array}$} & 0.0629208 \\
\hline & $P$-value $=0,9867 \geq 0,05$ \\
\hline
\end{tabular}

Note: $\mathbf{A D S}=$ Adsorption, $\mathrm{I}=$ Illite, Do=Dolomite, $\mathrm{Fd}=$ Feldspar, $\mathrm{Cl}=$ Chlorite, $\mathrm{F}=$ Iron oxide, $\mathrm{Qz}=\mathrm{Quartz}$, 
Figure 4. Multiple Regression Analysis of permeability (Desorption).

\section{Plot of Desop}

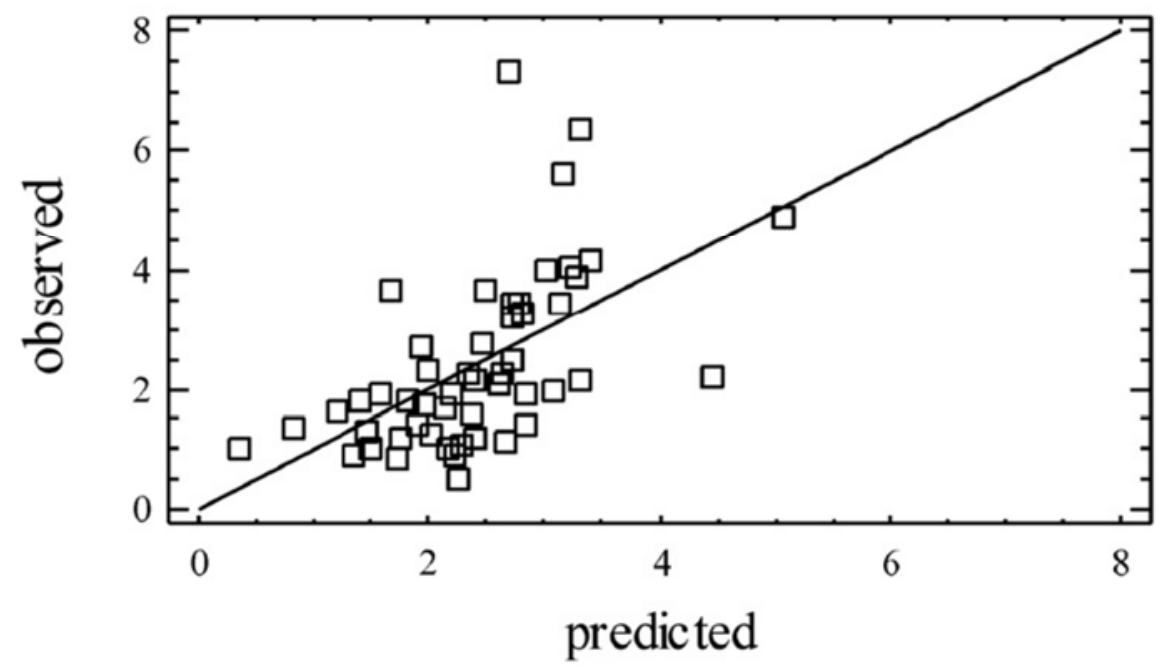

$\mathrm{ADS}=12,356 \mathrm{E}-13+0,159895 \mathrm{E}-13^{*} \mathrm{SiO}_{2}+0,678781 \mathrm{E}-13^{*} \mathrm{Al}_{2} \mathrm{O}_{3}+0,3305599 \mathrm{E}-13 * \mathrm{Fe}_{2} \mathrm{O}_{3}+0,292665 \mathrm{E}-13{ }^{*} \mathrm{CaO}-1,43234 \mathrm{E}-13 * \mathrm{~K}_{2} \mathrm{O}-0,1609 \mathrm{E}-13^{*} \mathrm{MgO}+6,33518 \mathrm{E}-$ $13^{*} \mathrm{MnO}-1,13762 \mathrm{E}-13^{*} \mathrm{Na}_{2} \mathrm{O}-12.3763 \mathrm{E}-13^{*} \mathrm{P}_{2} \mathrm{O}_{5}-5,00401 \mathrm{E}-13^{*} \mathrm{TiO}_{2}-0,253142 \mathrm{E}-13^{*} \mathrm{Cl}-0.272725 \mathrm{E}-13^{*} \mathrm{Do}-0.221849 \mathrm{E}-13^{*} \mathrm{f}-0,259094 \mathrm{E}-13^{*} \mathrm{Fd}-0.270285 \mathrm{E}-13^{*} \mathrm{I}-$ $0,246475 \mathrm{E}-13^{*} \mathrm{Qz}$

\begin{tabular}{|c|c|}
\hline \multicolumn{2}{|c|}{ Multiple Regression Analysis } \\
\hline \multicolumn{2}{|c|}{ Dependent variable: ADS } \\
\hline \multicolumn{2}{|c|}{ Selection variable: Samples } \\
\hline Parameter & P-Value \\
\hline Constant & 0,5430 \\
\hline $\mathrm{SiO}_{2}$ & 0,3107 \\
\hline $\mathrm{Al}_{2} \mathrm{O}_{3}$ & 0,0607 \\
\hline $\mathrm{Fe}_{2} \mathrm{O}_{3}$ & 0,5213 \\
\hline $\mathrm{CaO}$ & 0,3007 \\
\hline $\mathrm{K}_{2} \mathrm{O}$ & 0,0753 \\
\hline $\mathrm{MgO}$ & 0,7377 \\
\hline $\mathrm{MnO}$ & 0,6171 \\
\hline $\mathrm{Na}_{2} \mathrm{O}$ & 0,1109 \\
\hline $\mathrm{P}_{2} \mathrm{O}_{5}$ & 0,4866 \\
\hline $\mathrm{TiO}_{2}$ & 0,2781 \\
\hline $\mathrm{Cl}$ & 0,1087 \\
\hline Do & 0,0496 \\
\hline $\mathrm{F}$ & 0,2057 \\
\hline Fd & 0,1585 \\
\hline I & 0,0815 \\
\hline $\mathrm{Qz}$ & 0,0697 \\
\hline R-squared & 32,1283 percent \\
\hline \multicolumn{2}{|c|}{ Homoscedasticity residuals } \\
\hline Durbin-Watson statistic & $2,57197>1,4$ \\
\hline \multicolumn{2}{|c|}{ Normality residuals } \\
\hline \multirow{2}{*}{$\begin{array}{l}\text { Kolmogorov-Smirnov } \\
\text { Statistic DPLUS }\end{array}$} & 0,129185 \\
\hline & $P$-value $=0,3544 \geq 0,05$ \\
\hline
\end{tabular}

Note: Desop $=$ Desorption, $\mathrm{I}=\mathrm{Illite}, \mathrm{Do}=$ Dolomite, $\mathrm{Fd}=\mathrm{Feldspar}, \mathrm{Cl}=\mathrm{Chlorite}, \mathrm{F}=\mathrm{Iron}$ oxide, Qz=Quartz. 